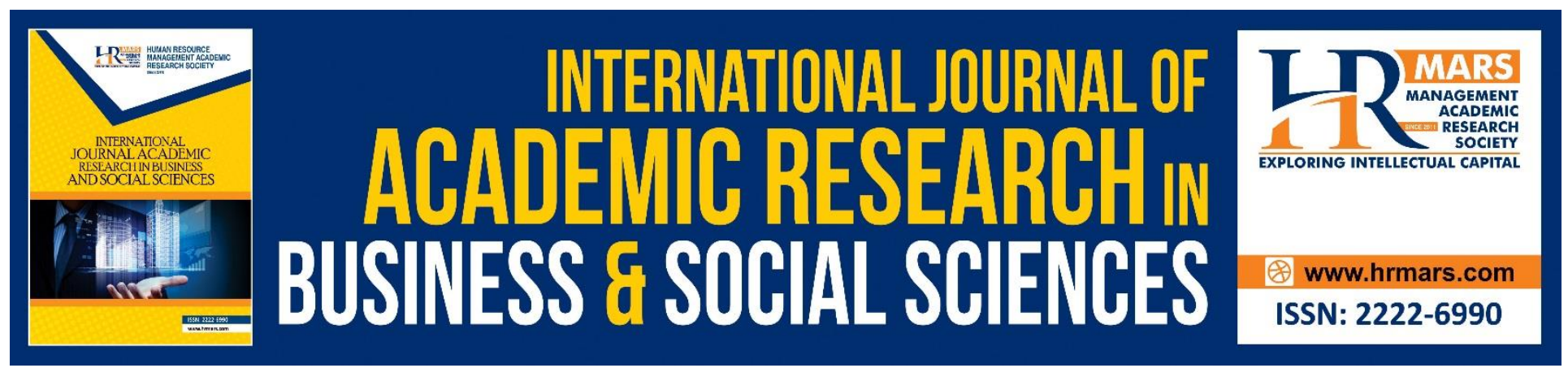

\title{
Introduction to Conceptual Analysis of Interpretation
}

\author{
Gina Emilia Tache
}

To Link this Article: http://dx.doi.org/10.6007/IJARBSS/v9-i2/5586

DOI: $\quad 10.6007 /$ IJARBSS/v9-i2/5586

Received: 29 Jan 2019, Revised: 19 Feb 2019, Accepted: 25 Feb 2019

Published Online: 01 March 2019

In-Text Citation: (Tache, 2019)

To Cite this Article: Tache, G. E. (2019). Introduction to Conceptual Analysis of Interpretation. International Journal of Academic Research in Business and Social Sciences, 9(2), 528-537.

\section{Copyright: (c) 2019 The Author(s)}

Published by Human Resource Management Academic Research Society (www.hrmars.com)

This article is published under the Creative Commons Attribution (CC BY 4.0) license. Anyone may reproduce, distribute, translate and create derivative works of this article (for both commercial and non-commercial purposes), subject to full attribution to the original publication and authors. The full terms of this license may be seen at: http://creativecommons.org/licences/by/4.0/legalcode

Vol. 9, No. 2, 2019, Pg. 528 - 537

Full Terms \& Conditions of access and use can be found at http://hrmars.com/index.php/pages/detail/publication-ethics 


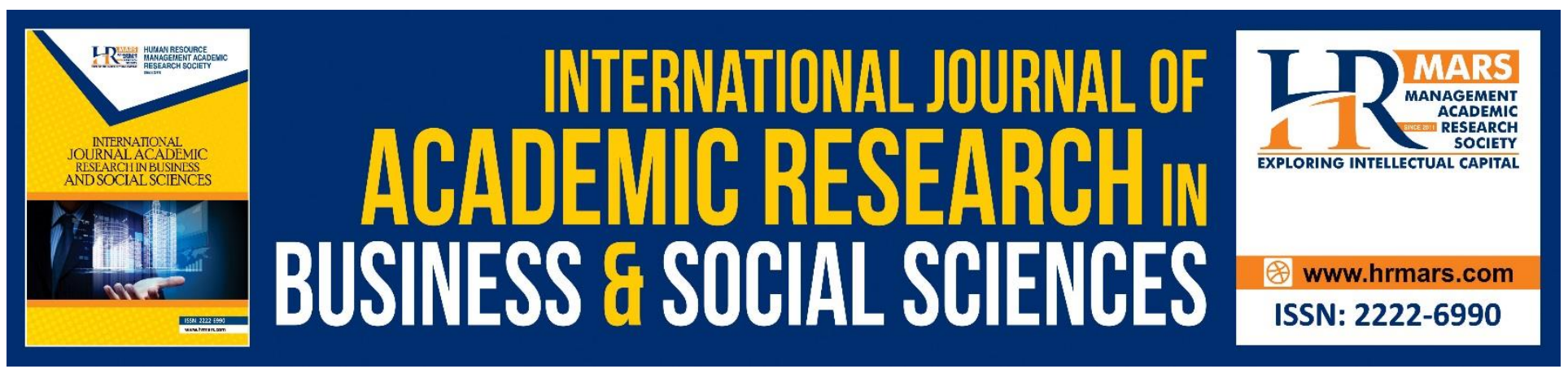

\title{
Introduction to Conceptual Analysis of Interpretation
}

\author{
Gina Emilia Tache \\ Juridical Researches Institute, Romanian Academy, Romania \\ Email: gina.tache@yahoo.com
}

\begin{abstract}
Interpreting in law, before being a moment of law enforcement, is the first operation that prepares and rationalizes the elaboration of the law, of any normative act, in general. What we consider to be necessary is that the prior application of the European Convention on Human Rights takes place not only in the case of conflict of laws but also in the case of non-compliance resulting from different interpretations of the legal provisions. From this justification, it is not difficult to observe that the European Union's normative acts apply as a priority in relation to national law.
\end{abstract}

Keywords: Legal Norms, Interpreting, Conflict Of Law, European Convention, Human Rights

\section{Introduction}

In the legal doctrine (Imre, 1964; Ceterchi, 1960; Voiculescu, 1966; Antoniu, 2006; Popescu, 2016; Humă, 2005; Vida et al, 2016; Craiovan, 2015; Popa, 2014; Popa et al, 2017; Popescu et al, 2008; Riteș, 2014), it has been rightly said that any human manifestation ${ }^{1}$, to the extent that it would be susceptible to different meanings and meanings, can be interpreted, that is, it may attract the need to reveal it meaning, meaning, and thereby its compatibility with certain exigencies, existing social requirements at a certain moment.

\section{Content}

In this regard, it was stated first that any of the above manifestations is attributed to a certain subjective sense, constituting a purely personal, individual interpretation of the gesture, the word, etc., in relation to the subject's mood ${ }^{2}$ or it may be attributed, in context, to an objective sense, that is, a meaning which corresponds with most people's opinion on the character of the above gesture ${ }^{3}$.

\footnotetext{
${ }^{1}$ Gesture, word, expression, behavior

${ }^{2}$ For example, the gesture of taking a person from the arm can be subjectively taken as violence, an act of forcibleness or forcibleness),

${ }^{3}$ Taking the arm, in the opinion of the other people, has the character of an act of friendship, closeness, affection).
} 
(Antoniu, 2006) On the one hand, it is also apparent in the same manifestation that a seeming sense ${ }^{4}$ (Antoniu, 2006), or a real sense ${ }^{5}$ (Riteș, 2014).

Secondly, it is not difficult to observe that the ambiguity of meaning can affect not only a gesture but also a word. ${ }^{6}$ (Beiser, 2012) As such, the one who asserts that his friend at that moment has climbed a step may refer, in context terms, to his own sense of the step, that is, to the components of a stair that his friend is just climbing. But it is possible for the person to make the aforementioned statement about her friend, referring to the notion of step in a figurative sense, that is to say, a step in the social hierarchy. In this case, the word being used is objectively susceptible to several meanings ${ }^{7}$ (homonymous), the correct interpretation will depend on the context in which the word is used. (Popescu et al, 2017).

In addition, it has been shown that ambiguities may also exist in the case of expressions. In this regard, we are evoking some examples to better understand the situation. ${ }^{8}$

In the light of what has been shown here, (Bartfeld, 1957; Dongoroz, 1939) we can conclude, like other authors ${ }^{9}$ that the misinterpretation of the meaning of a gesture, word, expression, reasoning in colloquial language could affect communication between the participants and provoke the occurrence of misunderstandings between partners and even conflicts, and on the other hand it seems to us that they are in principle clarified by the additional applications given by the participants in the discussion, in order to avoid any misunderstanding.

Thirdly, we note that human interpretations are susceptible to interpretation. In this respect, we exemplify the musical, theatrical, technical, the artistic creations, etc., not only in the material execution of a work of this character ("interpreting" a symphony in the sense of executing it), but also the revelation of certain meanings, meanings of creation related to the tastes, feelings, feelings of others as well as of the interpreter himself. From here, it seems to us that a possible misinterpretation of execution or disclosure of the meaning of an artistic work could compromise the quality of the work of art, preventing the correct transmission of the artistic content of the work.

Finally, we add a last point, naturally, to us about the issue that concerns us, namely the rules to be observed in society. Theoreticians show, in this sense, that they are: undying rules, i.e. moral, cohabitation, politeness, etc. and legal rules i.e. rules enshrined in a normative act adopted by the

\footnotetext{
${ }^{4}$ For example, taking the arm with soothing words could have the apparent sense of friendship

${ }^{5}$ Arm-taking with a clamp with an unusual force of the victim's arm, even with soothing words, may have the real meaning of aggressive, rudimentary action

${ }^{6}$ For example, Savigny said: "It is the word that interferes with the transposition of the legislator's thinking into our thinking."

${ }^{7}$ Homonymous

${ }^{8}$ For example, to take into account may mean "to take account of something" or, in its own right, in the field of accounting, "keeping an account" means keeping records of a person's payments and payments, as well as full reasoning for example, when someone expresses: "we are not as prepared as some of the present," he may point out a real situation, have the character of an objective finding, as the comparison might have an ironic sense.

${ }^{9}$ George Antoniu
} 
competent authority and whose observance is mandatory, being ensured by applying penalties to recalcitrant recipients (Ceterchi, 1960; lampolsaia, 1955). In this case, we note that an identical point of view is expressed in an article of the late, professor, scientific researcher emeritus George Antoniu (Antoniu, 2006). According to the author, an error in the interpretation of a rule, legal or unbridled, could lead either to its observance in situations when it could not be respected, or to its nonobservance even though it had been imposed. Hence, it appears that the wrong interpretation of a rule can only occur when such rules exist and are known by the subject. (Avrigeanu, 2005) ${ }^{10}$. At the same time, (Antoniu, 2006) it has been said that there will be no interpretation, except in relation to the non-judicial or juridical rules (Antoniu et al, 2015; Popescu, 2000; Popa, 1994; Vonica, 2000; Craiovan, 1992; Ciobanu, 1991; Demeter et al, 1962; Stancu, 2003; Wright, 1982) that are susceptible to multiple meanings, due to the ambiguity of the words or expressions used in the formulation of the rule or other circumstances, and not when the rule has only one meaning ${ }^{11}$.

We also note that among the above rules, the legal ones are also subject to the need to be interpreted, their correct understanding being imposed by the serious consequences that any misunderstanding of the norm would entail. It was not accidental in the doctrine that, in order for the legal norms to influence the social relations, because these mandatory rules of conduct, expressing the will of the state, to achieve the purpose in which they were created, it is necessary that they to realize that their provisions are to be accomplished. (Lupu et al, 2001). ${ }^{12}$

Then, we notice that, in the view of other emeritus teachers ${ }^{13}$, the legal norm describes a model, a program, a standard, a standard of individual behavior, but not an ideal one, but a behavior that is in agreement with social requirements, with the interests of society. The norm expresses the representation of the legislator on the possible conduct and owed by the subjects involved in social relations (Popa, 1994).

In the view of Professor Vintilă Dongoroz, the legal norm appears as an epiphenomenon of the life of relationship, that is, a phenomenon derived from the existence of society and which finds its explanation in the existing relations between the members of the social group ${ }^{14}$ (Dongoroz, 1939).

\footnotetext{
${ }^{10}$ We mention in this respect that the researcher dr. Tudor Avrigeanu, CS II at the Institute of Legal Research, Academician Andrei Rădulescu "of the Romanian Academy, wonders whether it constitutes any legal norms, from the point of view of the inaccurate formal validity," right " regardless of their content? Is it "a right" and a rule that would hold criminal liability even to the one who had no means of knowing certain criminal law rules, or one that would extend complicity and approve a post-factual act to its execution?

${ }^{11}$ For example, the rule that religious marriage can only be done after a marriage in front of the civilian officer, or the rule that the salvation of the homeland even at the cost of life is the supreme moral duty

${ }^{12}$ For example, according to François Terré, the legal norm emerges from the need to combat violence and arbitrariness in social relations. In this thesis, Professor George Antoniu made the observation that although the author speaks of a repulsion of the people against these evils, we must admit that this sentiment was not the basis for the emergence of the legal norm but the interest of the social group survival.

${ }^{13}$ Nicolae Popa

${ }^{14}$ Relationships that, increasingly becoming adversary, public authority to legal constraint
} 
In addition to the cited authors, other authors (Dogaru et al, 2006; Stancu, 2003) define the legal norm as a general rule of general and impersonal conduct, aiming at the intersubjective outward appearance of the particular consciousness exalted to its universality, aiming to create a typical behavior for individuals according to the social model necessarily pursued by its legitimacy the level of collective consciousness and which, if necessary, can be achieved through coercion.

In foreign literature, the legal norm is born, says Jakobs, within and as a result of a "normative agreement"15 among the members of society. However, they do not appear in their natural constitution of individuals before society: such an alignment would lead to the placement of the social sense and the norms expressing this meaning on an essentially natural level constituted as a sum of individual wills. (Jajobs et al, 1999; Avrigeanu, 2005). On the contrary, the meaning - what the members of society have objectively to achieve - is in an objective plan and, in this objective plan, members of society need to be aware of it. No less, however: "A rule that no longer counts legitimate except for the police, the latter having its force on its part, appears outside the police not as a valid norm, but as a formula of the conditions in which it is applied compulsion ${ }^{16}$ (Jajobs et al, 1999; Avrigeanu, 2005)". In this context, in Jakobs, (Avrigeanu, 2005) the legal norm and the construction of the person in law must not appear as a firewall of instrumental social communication, in which norms appear as instruments of the strongest force over others (Jakobs, 1993). The norm must therefore be legitimate and this means that the participants in the normative understanding from which the legal norm is born must already appear as "persons in law", thus recognizing each other as potential subjects of rights and obligations; this mutual recognition becomes constitutive for the constitution of legal subjectivity, denial of the norm by the perpetrator is at the same time a denial of his own subjectivity (Jakobs, 1999; Avrigeanu, 2005).

We cannot overlook the fact that in Hegel the right is grounded in freedom and understood as a relationship between more free wills belonging to some people (Hegel 1998).

At the same time, it has been argued that the norm, in the sense of Hart and Austin, is prescription, order or command, or, in Kelsen's refined terminology, the norm is an interpretative-volitional scheme. Moreover, it was noted that, in Kelsen's view, the hierarchy of legal norms in relation to the fundamental norm confers to each rule a certain legal force, which gives a state-owned society the status of a state governed by the rule of law (Kelsen, 1991; Moroianu, 1998).

From this analysis, it follows that the legal norm is created for the purpose of determining a certain conduct for the purpose of its enforcement by law enforcement bodies under certain conditions and with the help of state constraints.

As we can see, the rule of law arises from the application of the norm, implicitly from the conversion of the virtual efficiency of the norm into effective, effective efficiency. In this regard, it has been

\footnotetext{
${ }^{15}$ Normative Verständigung

${ }^{16}$ Formel für die Bedingungen von Zwangsanwendung.
} 
emphasized in the literature that the legal norm, by its mere entry into force, does not contribute to the creation and consolidation of the law order, but only by its interpretation in life, in the social relations (Craiovan, 2011; Humă, 2005).

Starting from this vision, we could say, in agreement with other authors (Djuvara, 1930; Craiovan, 2010; Dănișor et al, 2006) of the general theory of law, that the norm's entry into force is only the premise of creating the legal order, but only its practical application (Imre, 1964; Pașalega, 1960; Popescu, 2016; Popa, 2014), by effectively shaping people's behavior after prescriptions the norm contributes to the creation of the rule of law. The same idea is found in other authors ${ }^{17}$. Even more so, the authors argue that state objectives cannot be achieved only by developing multiple and diversified rules, but that these rules need to be properly applied (Savu, 2003). Therefore, interpreting in law, before being a moment of law enforcement, is the first operation that prepares and rationalizes the elaboration of the law, of any normative act, in general; to be a manifestation of will, the creation of the right must be justification and argumentation of the will in question, of course - based on objective principles and conditions (Arnauld, 1972; Eremia, 1995; Riteș, 2014). It has the nature of interpretation to make the right to progress. Without the original interpretation, the legal system (Vida et al, 2016; Stancu, 2009) remains stuck; without the "unscrewing" interpretation, the mechanism risks being stuck.

But beyond this point, legal science also shows that the legislator's wisdom must be found in the balanced decision of the judge; the initial moment of the social needs assessment should be completed with the next moment of realization of the right.

At the same time, it has been pointed out in addition that the observance of the rule of law, either as a voluntary act, consciously or as a constraint, as an act imposed by the public authority, creates in the social relations a state of safety, stability, order and discipline absolutely necessary for the good coexistence of the members of society and the proper development of their activity (Popa, 2014; Antoniu, 2014) ${ }^{18}$. It has been observed in this respect that the legal order, i.e., ${ }^{19}$ with which they coexist and influence one another (Ionescu, 1964; Antoniu, 2015; Dongoroz, 1939).

We note, therefore, that interpretation plays an important role in the law making process. Taking into account this reality, we affirm as other authors (Dabin, 1935; Terre, 2993; Popescu, 2016), only by interpretation right becomes an art first of all the art of legislating and, second, the art of acting as right as possible in the realization of the law. We add to the conclusion that very interesting reflections, which we believe, are of great interest even nowadays, can be found in a paper called Ioan Ionescu-Dolj, New Legislative Technique, 1939. For example, the author we refer to states that

\footnotetext{
${ }^{17}$ For example, Sofia Popescu, Szabó Imre, Dumitru Pasalega, Nicolae Popa.

${ }^{18}$ Function of preserving, defending and guaranteeing the fundamental values of societies

${ }^{19}$ The order imposed by the legal constraint, is the nucleus of the social order, the main instrument for ensuring order in social life, without thereby removing the other ways of ensuring a good coexistence between people ordinary, religious order, moral order
} 
"as the judge, in the application of the law - in addition to legal knowledge, must possess the art of judging, so too the legislator, besides the knowledge of the matter in which he wants to legislate, must posession and legislative technique or the art of legislative constructivism" (Popescu et al, 2006).

Moreover, we add the fact that in the literature (Delmas-Marty et al, 2005; Antoniu, 2008) it was revealed that both the lawmaker and the law enforcement bodies carry out their specific activities not only on the basis of the knowledge of the realities and the issues raised by these realities internally, but also on the basis of regulatory requirements imposed by supranational authorities. (Fuerea, 2016; Renucci, 2013; Diaconu, 2011; Munteanu et al, 2003; Cosmovici, 1991; Popescu, 2005; Popescu, 2005; Vida et al, 2016). For example, in the case of Simmenthal, the Court of Justice of the European Communities, by a judgment of 9 March 1978, held that the judge is required to apply the European (Community) rule by waiving its national law if this contradicts the European one. Hence, we conclude that the public authorities of the member states of the Council of Europe that have ratified the European Convention on Human Rights must ensure the proper application of both the national legislation and the normative acts of C.E.D.O. Even more so, they have to respect the interpretations and accept the meaning given to the norms of these supranational normative acts and the jurisprudence of the Court of Justice of the European Union.

\section{Conclusions}

What we consider to be necessary is that the prior application of the European Convention on Human Rights takes place not only in the case of conflict of laws but also in the case of non-compliance resulting from different interpretations of the legal provisions ${ }^{20}$. From this justification, it is not difficult to observe that the European Union's normative acts apply as a priority in relation to national law.

We therefore share the view expressed in the literature that the rules of interpretation resulting from the jurisprudence of the Court of Justice of the European Union of these normative acts have a priority character, as a rule. We remind that art. 4 of the Civil Code states that, in the matters governed by this Code, the provisions on the rights and freedoms of persons shall be interpreted and applied in accordance with the Constitution, the Universal Declaration of Human Rights, the covenants and other treaties to which Romania is a party.

In addition to this justification, we also add that some authors show that, according to ECE case law, the EU Member States have the obligation to interpret and apply their own legislation in accordance with the provisions of C.E.DO. Therefore, it is stated in the doctrine that, in the event of a legal conflict, international human rights acts will prevail, according to the principle of priority of international regulations and European law in this field. On the other hand, we notice that there are

\footnotetext{
${ }^{20}$ See Costa c .Enel
} 
INTERNATIONAL JOURNAL OF ACADEMIC RESEARCH IN BUSINESS AND SOCIAL SCIENCES

Vol. 9, No. 2, Feb, 2019, E-ISSN: 2222-6990 C 2019 HRMARS

also some exceptions, such as those provided in paragraph 2 of article 4 of the Civil Code in force, according to which priority will be given to the internal law, if it is more favorable.

\section{References}

Antoniu, G. (2006). Reflecţii asupra interpretării legii penale, din perspectivă europeană (I), RDP nr. 2, p.9.

Antoniu, G. (2008), Legea penală română în condiţiile postaderării, RDP nr.3.

Antoniu, G. (2014). Reflecţii asupra interpretării legii penale, din perspectivă europeană, SCJ-4.

Antoniu, G. (2014). Tratat de drept penal, vol. I, Ed. Universul Juridic

Antoniu, G. (2015). Tratat de drept penal, vol. I, Ed.Universul Juridic.

Arnaud, A.-J. (1972). Le medium et le savant. Signification politique de l'interprétation juridique, Archives de Philosophie du Droit", Sirez, Paris, XVII.

Avrigeanu, T. (2005). Controversa filosofică şi evoluţia dogmaticii penale, Revista Studii de Drept Românesc, nr.1-2.

Bartfeld, L. (1957). Norma Juridică şi raportul juridic, Justiţia Nouă nr. 2.

Ceterchi, I. (1960). Teoria generală a statului şi dreptului, partea I-a, Ed. Didactică şi pedagogică.

Ciobanu, D. (1991). Introducere în studiul dreptului, Universitatea Ecologică, Bucureşti.

Cosmovici, P.-M. (1991). Les communaité européennes et l'État de droit, în Revue roumaine des sciences juridiques, Nr.1-2.

Craiovan, I. (1992). Introducere în studiul dreptului, Bucureşti.

Craiovan, I. (2011). Tratat elementar de teoria generală a dreptului, Ed. ALL BECK, Bucureşti, Craiovan, Ion (2010). Filosofia dreptului sau dreptul ca filosofie, Ed. Universul Juridic, Bucureşti.

Craiovan, Ion (2015). Tratat de teoria generală a dreptului, ediţia a III-, revăzută şi adăugită, Ed. Universul Juridic.

Dabin, J. (1935). La technique de l'élaboration du droit positif, Bruxelles, Ed. Bruylant.

Dănişor, D. C.; Dogaru, I. (2006). Teoria generală a dreptului, Ed. C.H.Beck, Bucureşti

Delmas-Marty, Mireille în lucrarea Geneviéve Guidicelli-Delage, Stefano Manacorda (2005). L'integration pénale indirecte. Société de législation comparée, Paris.

Demeter, I.; Ceterchi, I. (1962). Introducere în studiul dreptului, Ed. Ştiinţifică, Bucureşti.

Diaconu, Nicoleta (2011). Dreptul Uniunii Europene, Tratat, ediţia a II-a, revizuită, Ed. Lumina Lex, Bucureşti.

Djuvara, M. (1930). Teoria generată a dreptului, vol. II, Ed. Librăriei Socec, Bucureşti.

Dogaru, I.; Dănişor, D.C.; Dănişor, Gh. (2008). Teoria generală a dreptului, Ed. C.H.Beck, Bucureşti

Dongoroz, V. (1939). Tratat.

Eremia, M.-C. (1995). Interpretarea juridică, Ed. All, Bucureşti.

Fuerea, A. (2016). Tratatul de aderare a României la UE în Manualul Uniunii Europene, ediţia a VI-a, Ed. Universul Juridic, Bucureşti.

Hegel, G. W. F. (2015). Principiile filosofiei dreptului, Ed. Univers Enciclopedic World

Humă, I. (2005). Aspecte problematice privind componenta teleologică a interpretării juridice, în Dreptul românesc şi Constituţia europeană, Din comunicările prezentate la sesiunea ştiinţifică a Institutului de Cercetări Juridice, Ed. Tempus. 
INTERNATIONAL JOURNAL OF ACADEMIC RESEARCH IN BUSINESS AND SOCIAL SCIENCES

Vol. 9, No. 2, Feb, 2019, E-ISSN: $2222-6990$ ๑ 2019 HRMARS

Humă, I. (2005). Cunoaştere şi interpretare în drept. Accente axiologice, Ed. Academiei Române, Bucureşti.

Iampolsaia, J.A. (1955). Despre norma juridică şi raporturile juridice, Justiţia Nouă nr.2.

Ionescu, S. (2008). Justiţie şi jurisprudenţă în statul de drept, Ed. Universul juridic, Bucureşti.

Jakobs, G. (1999). Zur Genese von Rechtsverbindlichkeit, în: G. Höver (Hrsg.), Verbindlichkeit unter den Bedingungen der Pluralität, Hamburg.

Jakobs, G. N.; Gesellschaft, P. (1999). 2. Auflage, Berlin.

Kelsen, H. (1991). General Theory of Norms (transleted by Michel Martney), Oxford, Clarendon Press. Lupu, Gh.; Avornic, Gh. (2001). Teoria generală a dreptului, Ed. All Beck, Bucureşti, Moroianu, G. E. (1998). Actualitatea normativismului kelsian, Ed. All Beck, Bucureşti.

Nicolescu, I. F. (2006). Interpretarea normei juridice, tradusă din limba unui stat membru al Uniunii Europene într-o altă limbă a unui alt stat membru al Uniunii Europene, in Integrarea europeană şi dreptul românesc, din comunicările prezentate la sesiunea ştiinţifică a Institutului de Cercetări Juridice al Academiei Române, Ed. Tempus.

Popa, N. (1994). Teoria generală a dreptului, Ed. Actami, Bucureşti.

Popa, N. (2014). Teoria generală a dreptului, ediţia 5, Editura C.H. Beck.

Popa, N. (coordonator); Anghel, Elena; Ene-Dinu, Cornelia; Spătaru-Negură, Laura (2017). Teoria generală a dreptului, Caiet de seminar, ediţia 3, Ed. C.H.Beck.

Popescu, D. (2005). Raportul dintre dreptul internaţional şi dreptul european, în Dreptul românesc şi Constituţia europeană, vol.III, Ed.Tempus.

Popescu, S. (2000). Teoria generală a dreptului, Ed. Lumina Lex, Bucureşti.

Popescu, S. (2005). Statul de drept şi integrarea europeană, din perspectiva dreptului comparat, în Dreptul românesc şi Constituţia europeană, vol.III, Ed.Tempus.

Popescu, S. (2016). Teoria generală a dreptului Ştiinţa dreptului, in Jus est ars boni et aequi, Ed. Pro Universitaria.

Popescu, S.; Cioara, C. ; Tăndăreanu, V. (2008). Aspecte practice de tehnică şi evidenţă legislativă, Ed. Monitorul Oficial, Bucureşti.

Popescu, S.; Prelipceanu, T. (2006). Personalităţi ale Consiliului Legislativ de-a lungul timpului, Ed. a II-a revizuită şi adăugită, Lumina Lex, Bucureşti.

Renucci, J. -F. (2013). Droit, européen des droits de l'homme, 2e édition.

Riteş, L. (2014). Interpretarea. Instituţie fundamentală a dreptului, Ed.Universul Juridic.

Roxana M., Bogdan B., Tendinţe actuale de reformare a Uniunii Europene, Dreptul românesc şi integrarea europeană, vol. I, 2003, Ed. Tempus, Bucureşti

Savu, I. (2003). Interpretarea dreptului, Ed. Fundaţiei „România de Mâine”, Bucureşti.

Stanciu, L. (2009). Evoluţia şi limitele noţiunii de interpretare, în Studii juridice în onoarea prof.univ.dr.George Antoniu, Ed. Hamangiu.

Stancu, R. (2003). Norma juridică, Ed. Tempus, Bucureşti.

Stancu, R. (2002). Norma juridică, Ed.Tempus, Bucureşti.

Szabó, I.(1964). Interpretarea normelor juridice, Ed. Ştiinţifică, Bucureşti.

Terré, F. (2003). Introduction général au droit, 6 edition, Dalloz.

Vida, I. ; Vida, I. C. (2016). Teoria generală a dreptului, Curs universitar, Ed. Universul Juridic, Bucureşti. 
INTERNATIONAL JOURNAL OF ACADEMIC RESEARCH IN BUSINESS AND SOCIAL SCIENCES Vol. 9, No. 2, Feb, 2019, E-ISSN: 2222-6990 @ 2019 HRMARS

Voiculescu, M. (1966). Norme morale şi norme juridice, Justiţia Nouă, nr. 2.

von Wright, G.H. (1982). Normă şi acţiune, Ed. Ştiinţifică şi Enciclopedică, Bucureşti, Vonica, R.P. (2000). Introducere generală în drept, Ed. Lumina Lex, Bucureşti. 